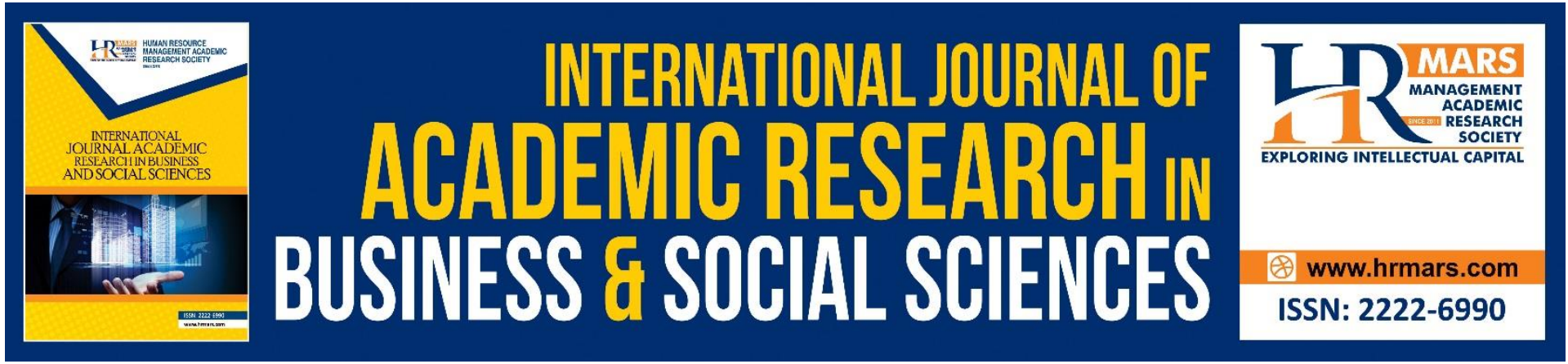

\title{
Metadiscourse in 2019 Malaysia Festive Television Advertisements
}

Nur Widad Roslan, Siti Nur Aliaa Roslan, Nur Maisarah Roslan, Suraya Amirrudin

To Link this Article: http://dx.doi.org/10.6007/IJARBSS/v11-i8/10064

DOI:10.6007/IJARBSS/v11-i8/10064

Received: 07 June 2021, Revised: 13 July 2021, Accepted: 02 August 2021

Published Online: 09 August 2021

In-Text Citation: (Roslan et al., 2021)

To Cite this Article: Roslan, N. W., Roslan, S. N. A., Roslan, N. M., \& Amirrudin, S. (2021). Metadiscourse in 2019 Malaysia Festive Television Advertisements. International Journal of Academic Research in Business and Social Sciences, 11(8), 1220-1241.

Copyright: (c) 2021 The Author(s)

Published by Human Resource Management Academic Research Society (www.hrmars.com)

This article is published under the Creative Commons Attribution (CC BY 4.0) license. Anyone may reproduce, distribute, translate and create derivative works of this article (for both commercial and non-commercial purposes), subject to full attribution to the original publication and authors. The full terms of this license may be seen

at: http://creativecommons.org/licences/by/4.0/legalcode

Vol. 11, No. 8, 2021, Pg. 1220 - 1241

Full Terms \& Conditions of access and use can be found at http://hrmars.com/index.php/pages/detail/publication-ethics 


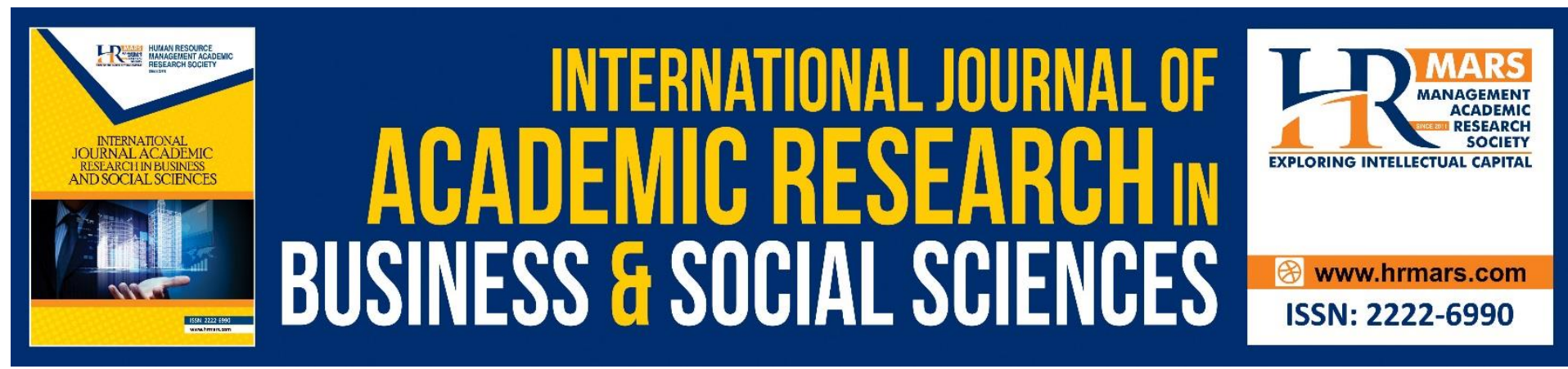

\title{
Metadiscourse in 2019 Malaysia Festive Television Advertisements
}

\author{
${ }^{1}$ Nur Widad Roslan, ${ }^{2}$ Siti Nur Aliaa Roslan, ${ }^{3}$ Nur Maisarah \\ Roslan, ${ }^{1}$ Suraya Amirrudin
}

${ }^{1}$ Faculty of Business, Information and Human Sciences, Infrastructure University Kuala Lumpur (IUKL), Kajang, 43000, Selangor, Malaysia, ${ }^{2}$ Faculty of Engineering, Science \& Technology, Infrastructure University Kuala Lumpur (IUKL), Kajang, 43000, Selangor, Malaysia, ${ }^{3}$ Centre for Preparatory Studies and Languages Al-Madinah International University, 57100 Kuala Lumpur, Malaysia

Email: widad.roslan@gmail.com

\begin{abstract}
Festive television advertisements in Malaysia have been on a rise lately as viewers are always waiting for brands to release their advertisements for every festive season and would compare with amongst the brands. It is important to critically understand and create quality content for the festive television advertisement. This is a qualitative study that analysed 29 festive television advertisements from the year 2019 and looked at the presence and the usage of the metadiscourse in the advertisements. The results of the study showed that the most common metadiscourse used in festive television advertisement is interactional resources in which it was a self-mention used by all brands. Self-mention is the advertisement mentioning the brand name itself in the advertisement. Overall, it shows that although festive advertisements often use the emotional route, in branding, brands are still in used in the festive advertisements to increase brand recognition and brand recall. It is hoped that the future study could focus on the element of metaphor in the festive television advertisement. Keywords: Critical Discourse Analysis, Metadiscourse, Festive, Television Advertisement
\end{abstract}

\section{Introduction}

Television is an electronic device used to transmit information towards the viewers. Often so television is used by most brands to advertise their product or services. With the rise of digital advertising, television advertising remains as the most used platform preferred by brands due to the fact that most television viewers watch television when they are at home (Kuyucu, 2020). Advertising a product or service can be challenging to the advertisers as different elements are used to create the content of the advertisement as the objective is to influence current and potential consumers as well as create content that is interesting and entertaining (Kellner, 2018). However, the content in an advertisement differs according to the type of advertisement being made. Product or service focused advertisements can be very hard-sell as they need to influence viewers to buy the product or service (Turow, 2018). But festive based advertisements normally use the emotionally approach to gain that trust, sympathy 
and empathy with the audience (Sualman et al., 2021). With this, the content creation of television advertisement is important, and the way to critically analyse television advertisement content to make sure it has the content needed is analysing the metadiscourse present in the television advertisement. Hyland (2017) had mentioned that metadiscourse is used to describe what the content means in texts that are interactional and interactive resources. By analysing the metadiscourse in the festive television advertisement, it will allow a more in-depth analysis of the content used.

Advertising is one of the methods used by brands to disseminate information about their product or service. Advertising can be done on many platforms and one of them being the television. Television advertising has evolved tremendously throughout the years (Andrews \& Shimp, 2017). Some still think that television advertising is a traditional method and not many brands are using television to advertise their brands. However, television has changed and kept in contrast with the digital era that is happening now by introducing digital television and paid television where television is connected with internet and still serve its purposes as a television platform but in a more advanced setup as it is connected with the internet servers (Park et al., 2017). A study by Chakkambath (2017) had focused on television advertisement as the main medium of brands to advertise online learning and indeed it had impacted both male and female subjects and that both the genders showed similar behaviours of searching through the online shopping website that was advertised through television. This shows that television advertisements remain as the main medium to advertise although we have move into the digital era.

Besides advertising on television, the content of the advertisement is also important and it always depends on the objective of the brands as well as the target audience. Roslan et al (2021) had mentioned that a brand's target audience often influences the content of the television advertisement as the main objective to create an advertisement is to influence of inform about the brands product or services. Other than the audience, another factor influencing the content of the television advertisement is when the advertisement is being advertised. Sualman et al., (2021) explained that often for different type of advertising such as advertising during a festive celebration, the content of the advertisement is more emotional oriented as opposed to the normal product centric advertisements as viewers always prefer to watch emotional advertisements during festive celebrations. This is because, during festive celebrations a lot of themes are used especially family oriented as festive celebration is often related to family. For example, a brand decides to advertise a product focused advertisement during a festive celebration and not develop an advertisement that is emotional, that will lead the viewers to think that the brand is not sensitive during festive season. Therefore, Sualman et al (2021) supports Roslan et al (2021) and further elaborated that the content of festive television advertisement differs as it is more emotional based.

Developing content takes into consideration many factors and one of them is the metadiscourse of the text Roslan et al., 2020). Hyland (2017) mentioned that metadiscourse is a word or a part of a text better known as an abstract that is often used to describe what the whole sentence means. Hyland $(1998,2005)$ further explained that metadiscourse is divided into two sections which are interaction resources which involve the reader with the text that they are reading through argument or interaction which consists of hedges, boosted, attitude markers, engagement and self-mention. The other section of metadiscourse is 
interactive resources of which is a part of the text that helps the reader to understand the context of the content. Metadiscourse allows a more in-depth understanding of the content and its uses. Once the writer/ copywriter understands metadiscourse, the use of the metadiscourse can be used in the correct places for its own purposes and helps to boost the festive television advertisement. The objective of this study is to identify and analyse the metadiscourse present in 2019 Malaysia festive television advertisement and its uses in the advertisement content.

\section{Methodology}

A qualitative study is used to analyse the objectives of this study. It focuses on the metadiscourse in 28 Aidilfitri, Chinese New Year, Deepavali, Gawai, Kaamatan and Christmas 2019 Malaysian television advertisements. The sample of this study was 10 Aidilfitri 2019 Malaysian television advertisements, 10 Chinese New Year Television Advertisements and 8 other festive television advertisements through video-tape and observation. 28 television advertisements are chosen to get ample data to be analysed as according to Matin \& Bateson (1986), the more data collected the better the results would be. Other than that, only 10 Aidilfitri television advertisements, 10 Chinese New year Television Advertisements and 8 Other Television Advertisements can be found on the platform "isentia" where television advertisement can be tracked. The platform can only be accessed through the advertising agencies who are given the only access. For other television advertisements, only 4 Deepavali, 1 Gawai, 1 Kaamatan and 2 Christmas television advertisement can be found on the platform. The copy of the television advertisements was analysed against Fairclough's (1995) second dimension of discourse analysis which is discourse practice analysis the sub category of metadiscourse. 
The advertisements analysed in this research was coded as below:

\begin{tabular}{|c|c|}
\hline Advertisement & Brand \\
\hline \multicolumn{2}{|c|}{$\begin{array}{c}\text { AIDILFITRI TV ADVERTISEMENT } \\
\end{array}$} \\
\hline A1 & PETRONAS \\
\hline $\mathrm{A} 2$ & MAXIS \\
\hline A3 & 100 PLUS \\
\hline A4 & HONG LEONG BANK \\
\hline A5 & TESCO \\
\hline A6 & MINISTRY OF ECONOMIC AFFAIRS \\
\hline A7 & TNB \\
\hline A8 & ASTRO \\
\hline A9 & MEDIA PRIMA \\
\hline A10 & UNIFI \\
\hline \multicolumn{2}{|c|}{ CHINESE NEW YEAR TV ADVERTISEMENT } \\
\hline A11 & 100 PLUS \\
\hline A12 & PALM OIL \\
\hline A13 & SP SETIA \\
\hline A14 & KFC \\
\hline A15 & MCDONALDS \\
\hline A16 & TNB \\
\hline A17 & IJM LAND \\
\hline A18 & MCDONALD TACTIAL \\
\hline A19 & HURIX \\
\hline A20 & VITAGEN \\
\hline \multicolumn{2}{|r|}{ OTHERS } \\
\hline \multicolumn{2}{|r|}{ DEEPAVALI } \\
\hline$A 21$ & PETRONAS \\
\hline A22 & TNB \\
\hline A23 & ASTRO \\
\hline A24 & ASTRO ULAGAM \\
\hline \multicolumn{2}{|r|}{ GAWAI } \\
\hline A25 & FINAS \\
\hline \multicolumn{2}{|r|}{ KAAMATAN } \\
\hline A26 & PETRONAS \\
\hline \multicolumn{2}{|r|}{ CHRISTMAS } \\
\hline $\mathrm{A} 27$ & FERRERO ROCHER \\
\hline A28 & KINDER JOY \\
\hline
\end{tabular}

\section{Results and Discussion}

Aidilfitri Television Advertisement

In A2 television advertisement, the metadiscourse was found in the L11 copy. The metadiscourse used was interactional resources of engagement marker; "Experiences are more meaningful when shared". This copy helps to build the relationship between the advertisement and the viewers in a form of giving advice. With this, it is to encourage the viewers through an engagement marker so that they make use of advice given to them in their lives. 
L10 This year he will get to feel the Takbir and join others celebrating for the first time in his life.

L11 In visual copy: Experiences are more meaningful when shared.

A3 on the other hand, used the interactional resources of self-mention. It can be identified in L5 "Thank you, sincerely from the heart", where the copy explicitly mentions the wish. It comes from the advertisement brand through the word "thank you, sincerely". Not only it was a self-mention, but also to show a personal message especially for the viewers.

L5 Thank you, sincerely from the heart.

L6 Narrator: Selamat Hari Raya Aidil Firtri

In A4 television advertisement, the use of self-mention was not as metadiscourse in the advertisement copy, but it was used through the character. The self-mention used the word "I, My and We", to as indicators and it is bolded below:

L1 I have 4 sisters

L2 My eldest sister, her name is Sara. She wants to be a Doctor

L3 My second sister's her name is Aliya. She's likes to cook. She wants to be a chef

L4 My twin sisters want to be famous.

L5 But we have never met

The metadiscourse used in A4 was to indicate the self-mention brand of advertisement with the personal view of viewers in referring to the character and these words "I, My and We" were present too. This was to show like the character was talking directly to the viewers, to have a more personal connection with the audience. A5 advertisement uses a similar metadiscourse in the television advertisement of self-mention through the character in the advertisement. Not only does A5 advertisement use self-mention, but also hedges. The selfmention used can be identified in L1, L2 and L7:
L1 I often ask a lot
L2 What is it that I need to do
L7 Because I realise every good deed that I do

The word "I" was used as self-mention in A5 television advertisement to the reference in the advertisement brand and through the character too. Another line that used self-mention can be seen in L10 "May this Hari Raya mean more with goodness shared together", the word "together" acts as a self-mention of the brand advertisement towards the viewers. Other than self-mention, hedges is also used in A5 advertisement which can be seen in L4 "Does it start from the heart that is sincere giving, without expecting a return?". The word "does it" indicates that the advertisement wants a full commitments to proposition within the sentence, hence starting the sentence with "does it", which acts as a hedge of interactional resources. This shows that both self-mentions and hedges were used as a metadiscourse in A5 television advertisement.

The metadiscourse used in the A7 television advertisement on the other hand was the attitude markers. The discourse used throughout $A 7$ television advertisement expresses the writer's or brands attitude in the advertisement. Through words in L1 "Yay Konvoi. This year, we are visiting all of Grandfather's siblings. It's really a lot.", L7 "Let's go everyone! There's a lot more house we need to visit", L15 "Let's go everyone! There's a lot more house we need 
to visit" and L17 "Every time we meet, brings a lot of meaning". It can be seen that through the attitude markers used, the metadiscourse the advertisement wants to deliver is that when you spend your time together, be it family and friends it brings a special meaning in yourself, therefore you should cherish all the time you spend together. A8 television advertisement metadiscourse was similar to A7, where A8 television advertisement metadiscourse highlighted the importance of being together as a family no matter the differences to make Raya more meaningful. It can be identified that the type of metadiscourse used is booster and self-mention. Booster can be seen in L1 "Every family must have different kind of attitudes, right?", where the sentence withholds the advertisements meaning in proposition by using the word "must have", that indicates the commitment of proposition, while the self-mention can be seen in L13 where it mentions "But when we are together, our Raya is perfect". The word "we" in interactional resources mean that it is an explicit reference towards the writer or in this case the advertisement's character that is giving the message across to the viewers. A9 television advertisement's metadiscourse on the other hand highlighted towards the viewers that you should be sincere in whatever you are doing, and with this, others too will be sincere to you. This can be identified through the storyline of the television advertisement, on how a person's sincere gesture makes others around them be sincere back to you. Selfmention can be seen in when describing the metadiscourse of the A9 television advertisement:

L61 The hero is he who shows concern for others.

L62 Lady: The hero is someone strong.

L63 Maznah: Yes. Even my plants are always fresh.

L64 Ah Keong Mother: The hero has enough love for everyone.

L65 Streetside boy: and he helps everyone, regardless of who they are.

The self-mention used from L61 throughout $L 65$ can be seen as describing the main character of the television advertisement that is a metaphor of the metadiscourse of the television advertisement that you do not need to be an actual hero to be a hero, but when you are sincere to others, they will be sincere to you too and will always be there to give a helping hand. This is further elaborated in L71 where the copy mentions "He always says Be Sincere to others and they will be sincere to us too", so in A9 television advertisement, the metadiscourse is clearly mentioned in L71 to tell the viewer's exactly what the advertisements message wants to deliver, which is to be sincere to other, and they too will be sincere to you. A10 on the other hand, uses booster interactional resources as their main resource to indicate the metadiscourse in the television advertisement. The booster "more" is used in L2, L3, L10, L15, L16, L17, L18 and L19 as below:

L2 Everyone calls me Leman LEBIH (MORE).

L3 My principle in life is...everything has to be MORE!

L10 Leman can give you more.

L15 Be like me - get lots MORE data!

L16 To me, Raya is a time for MORE!

L17 It has to be MORE...so if I...

L18 Sister: It's always MORE with you lah, Leman!

L19 Leman: But all this wanting MORE is not just for me alone.

The word "more" was used in total of 8 times in A10 television advertisement. It acted as a booster of the metadiscourse element in the advertisement to boost the product's benefit in the copy. The use of booster is also to give emphasis of force towards the main message that 
wants to be delivered in a text (Hyland, 2017). Therefore, the use of "more" as a booster in the television advertisement is to give emphasis on the product benefit.

\section{Chinese New Year Television Advertisement}

In A11 Chinese New year television advertisement, the metadiscourse appeared in L11 copy "There's nothing more important than a family reunion Celebrate a Golden Chinese New Year with 100PLUS" where it indicated that a family reunion is the most important thing than anything else during the Chinese New Year. The metadiscourse used was the interactional resource of self-mention, by mentioning the brand's name itself in L11 "100PLUS". It tells the viewers to always remember that family reunion is important, but also you should celebrate Chinese New Year with the brands product, hence including the self-mention in A11 television advertisement. A12 uses a similar interactional resource to $A 11$, but a different metadiscourse for the advertisement. In A12, the interactional resource of self-mention is used throughout the television advertisement as below:
L1 On our way to our new dream
L2 Our new home
L3 Our strides may differ
L4 Our pace uneven
L7 We build on each other's strengths
L8 And learn from each other's shortcomings.
L9 These are the seeds we've sown.
L10 The future we will reap.
L11 On this journey, together.

In L1, L2, L3, L4, L7, L8, L9, L10 and L11, words such as "our, we, each other's, we've and together" is used to indicate the self-mention. It is a metadiscourse used throughout the television advertisement to signify "togetherness", which is indicated clearly in L11 "On this journey, together".

Metadiscourse used in A13 television advertisement was the interaction resources of booster, attitude markers and self-mention. The booster used in A13 is mentioned in L1 "Grandfather: He lan Shui, the thing we most looked forward to every Chinese New Year", L3 "He Lan Shui. It would bring great happiness in me". The copy "most looked forward" in L1 and "it would bring great happiness" in L3, serves as a booster in the television advertisement to influence the viewers on describing the product to being one that the character looks forward to and brings happiness, hence the use of booster, which is to give more emphasis on the product in the television advertisement. Attitude markers used in A13 television advertisement can be seen in L3 "It would bring great happiness in me" and again in L6 "But now, it is tea that brings me great happiness", in both L3 and L6, it is an attitude marker, where the character in the television advertisement expresses the advertisements attitude that ants to be portrayed towards the viewers. This copy such as "tea brings me great happiness" was the example to convince viewers to also have the same attitude as the advertisement has. The last transactional resource used in A13 is self-mention, where it gives an explicit reference to the brand itself in L14 "Setia wishes you a Happy Chinese New Year. Stay Close". With this, it shows that in A13 television advertisement, booster, attitude markers and self-mention is used to shape the metadiscourse of the advertisement which is about togetherness of family during Chinese New Year. A14 television advertisement uses booster and self-mention in its advertisement. The booster use is to give emphasis on the products benefits with words used in the advertisement such as "bigger and more". The booster is used in: 
L9 Wait kid, there's more!

L10 Kid: More?

L11 Narrator: Yes, more!

L12 Fried mashed potato fingers! Go big with KFC celebration bucket. Bring more to the table.

The booster used in L4, L9, L10, L11 and L12 was to give more emphasis on the brands product benefits, hence exaggerating on the product with words such as bigger and more. To top the booster, the use of self-mention in mentioning the brand name itself is used twice in the television advertisement, once in L8 and again in L12:

L8 Kid: KFC!

L12 Fried mashed potato fingers! Go big with KFC celebration bucket. Bring more to the table.

As seen in L12, the explicit mention of the brand in the television advertisement. Therefore, it can be seen in A14 television advertisement that the metadiscourse is about the brand product which is giving more for the viewers.

A16 television advertisement uses hedges as the interaction resources for the advertisement, being a very short television advertisement that consists of 4 lines that does not reveal anything:
L1 Locked Lah
L2 Can fit meh?
L3 Yaass
L4 Will they escape?

The sentence withholds the writers or the advertisements full intention of the advertisement, therefore not much is being mention in the advertisement. Therefore, the metadiscourse is to no fully reveal the full message of the advertisement, but just the hedges. A17 television advertisement on the other hand uses self-mention by mentioning the brand itself in L7 to wish viewers "IJM land wishes everyone peace and harmony abundance of joy", which is an explicit mention of the brand in the television advertisement. It can be seen that the metadiscourse of A17 is about celebrating togetherness for all the festive celebrations as mentions in L6 "We celebrate every festive season together".

A18 television advertisement highlights more of the brand products, therefore booster and self-mention of the brand is mentioned in the advertisement. The booster used can be seen in L5 "Enjoy more abundance with the new fish prosperity burger" the word "more" is used as to give emphasis on the brands product in the television advertisement, while the selfmention of the brand is used in $\mathbf{L} 6$ to give a direct reference towards the brand "Only at McDonalds". A20 on the hand is similar to A19, where the transactional resource used to describe the metadiscourse is booster and self-mention. The booster in A20 can be identified in L6 "Because they drink Vitagen that consists of probiotics, hence they have a very good gut health, crystal clear in mind", the word "because they drink" in L6 indicates the boost which gives emphasis of force towards the brands product which is followed by the boosted word "Because they drink Vitagen", normally boosters is used to further convince the viewers on the product. Other than Booster, self-mention was used in mentioning the advertisement brand. The brand is mentioned twice in the television advertisement, once in L6 "Because they drink Vitagen that consists of probiotics, hence they have a very good gut health, crystal clear in mind" and again in L7 "Vitagen adhere to wish everyone Happy Chinese New Year!". 
The use of self-mention is to give an explicit mention of the brand in the television advertisement so that viewers are aware which brand the advertisement is from. With this, it can be seen that in Chinese New Year television advertisement, booster and self-mention is the most used interactional resource for metadiscourse.

\section{Deepavali, Gawai, Kaamatan and Christmas}

Other festive television advertisements such as Deepavali, Gawai, Kaamatan and Christmas also were using different types of interactional resources to convey their metadiscourse. It can be seen in A21, where the metadiscourse is clearly stated in L8 "An open heart, welcomes the most precious blessings", which means the main objective of A21 television advertisement is that we should all have an open heart when doing anything, and hopefully we will get unexpected blessings in return. The interactional resource used in A21 is attitude markers, as seen in L8 where, it expresses the advertisements attitude in the sentence, where the advertisement wants viewers to be open in doing anything to expect a blessing in life. Similar to A22, in A22 television advertisement, the metadiscourse can be identified again at the end of the advertisement in L14 "Even though time has changed and we have grown, our parents always make sure that we shine bright", where through attitude marker that expresses the writers attitude in television advertisement, is to convey towards the viewers that although it is the 20th century, our parents will always know what's the best for their child to make sure the child will be able to "shine bright" where ever they are. In A23 on the other hand, uses hedge to portray the metadiscourse in the television advertisement. Hedges according to Hyland (2017) is withholding the writers full commitment towards proposition, which in A23 television advertisement means no revealing much information of the messaging of the television advertisement, but concludes the advertisement with attitude marker which expresses the writer's attitude in the advertisement which is to wish the viewers a happy Deepavali as mentioned in L6 "We wish you a very happy Deepavali".

In A26 Kaamatan television advertisement, the element of metadiscourse on the other hand can be identified in L3 and L5, where L3 mentions "the most important gift is family and tradition" and L5 mentions "Family and tradition. A gift that actually resembles us", the metadiscourse mentioned in the A26 television advertisement is to tell the viewers that from the writer intention on the Kaamatan festive celebration, family and tradition is the most important gift during the important time. The sentence describing A26 metadiscourse uses attitude markers where it expresses the writer's attitude in the sentence. This can be seen in the word "the most important gift is family and tradition" which is what the writer wants to express through the television advertisement, but does not mean that it's relatable towards all viewers.

For Christmas festive television advertisement on the other hand uses engagement markers and self-mention in A27 as the interactional resource of metadiscourse. The engagement is mentioned in L2 "So enjoy the taste and festivities together with Ferero Rocher", where the word "so enjoy" is sued to build a relationship with the viewers by mentioning to them they should enjoy the product. Self-mention is also mentioned in L2, where it is an explicit mention of the brand itself in the television advertisement which is "Ferero Rocher". A28 on the other hand, uses the interactional resource of engagement marker and self-mention, which is similar to A27. The engagement marker used in A8 can be seen in L1 "Choose kinder joy, because of the delicious coco and milky cream with crispy wafer balls", the word "choose" 
indicates the engagement the television advertisement wants to have with the viewers, to make an illusion that they can choose the product in the advertisement, hence using the engagement marker. The self-mention on the other hand is mentioned in L3 which is "Merry Christmas with Kinder Joy", which is an explicit mention of the brand in the television to let viewers know the brand of the advertisement.

Overall, for the metadiscourse element, it can be seen that only interactional resources is used to portray the metadiscourse in many advertisements, and one advertisement can have more than one interactional resources. It can also be seen that self-mentions is the most used interactional resource of mentioning the advertisements brands normally mentioned at the end of the advertisement.

\section{Conclusion}

It is found in this study that metadiscourse is indeed present in the sample of Malaysia 2019 festive television advertisements. Interactional resources, one of the metadiscourse sub category was identified as the most used resources when it comes to festive advertisements. The findings also showed that one festive television advertisement has more than one type of interactional resources for the metadiscourse, as an advertisement can have a few objectives in its content. Subsequently, the study also showed that the metadiscourse of selfmention is the often used in the festive television advertisements as the brands of the advertisement is the self-mention that is most commonly used at the end of the advertisement. This research shows the importance of using critical discourse analysis of metadiscourse in the content of television advertisements and not just writing context. Other than that, analysing metadiscourse helps to identify the most common metadiscourse used and why certain advertisements use it in the given situation and how other brands can use metadiscourse in their contents. It is hoped that future research focuses more on the use of metaphor in the content of festive advertisements as metaphor is often used in emotional based advertisements. 


\section{References}

Chakkambath, R, S. (2017). The Impact of Digital Marketing with TV as a Mode of Advertisement. International Journal of Scientific Engineering and Research, 5(12), 8186.

Hyland, K. (2005). METADISCOURSE. London: Continuum

Hyland, K. (1998). Persuasion and context: The pragmatics of academic metadiscourse. Journal of Pragmatics, 30(4), 437-455.

Hyland, K. (2005). Stance and engagement: a model of interaction in academic discourse. Discourse Studies, 7(2), 173-192.

Hyland, K. (2017). Metadiscourse: What is it and where is it going?. Journal of Pragmatics, $113,16-29$.

Kellner, D. (2018). Television and the crisis of democracy. New York, NY: Routledge.

Kuyucu, M. (2020). Television and Advertising: The History of TV Advertising from and Industrial Look. International Social Mentality and Researcher Thinkers Journal, 6(29), 258-269.

Roslan, N. W., Abdul Halim, H., Abdul Jabar, M. A., \& Hassan, H. Z. (2020). The Importance of Product USP Mention in Milk Formula Television Advertisement. In Normaliza Abd Rahim (Ed). Penyelidikan Wacana; Teori dan Aplikasi. Pp. 137-134. Terengganu: Penerbit Universiti Malaysia Terengganu.

Park, W. Y., Gopal, A., \& Phadke, A. (2017). Energy savings opportunities in the global digital television transition. Energy Efficiency, 10, 999-1011.

Turow, J. (2018). The development of the modern advertising industry. In The Advertising Handbook (pp. 3-15). New York, NY: Routledge. 


\section{Appendices}

\begin{tabular}{|c|c|c|}
\hline Advertisement & Line & Full Copy \\
\hline \multirow{35}{*}{$\begin{array}{l}\text { A1 } \\
\text { Petronas }\end{array}$} & L1 & $\begin{array}{l}\text { Soraya: Lemongrass, pepper, tamarind slices, coconut milk, } \\
\text { kerisik, turmeric }\end{array}$ \\
\hline & $\mathrm{L} 2$ & Boss: Soraya \\
\hline & L3 & Soraya: Boss? \\
\hline & L4 & Boss: What are you up to? \\
\hline & L5 & Soraya: I'm practicing my Mum's rendang. \\
\hline & L6 & Boss: That's not it. Isn't your flight tonight? \\
\hline & L7 & Soraya: Your right boss. \\
\hline & L8 & $\begin{array}{l}\text { Father: Soraya, oh Soraya. You wanted to cook Mum's rendang? } \\
\text { What's taking so long. }\end{array}$ \\
\hline & L9 & Soraya: I'm done. Now you're handsome. \\
\hline & L10 & $\begin{array}{l}\text { Soraya: tamarind slices, coconut milk, kerisik, tumeric, } \\
\text { lemongrass, pepper. tamarind slices, coconut milk, kerisik, } \\
\text { tumeric, lemongrass, pepper. tamarind slices, coconut milk, } \\
\text { kerisik, tumeric }\end{array}$ \\
\hline & L11 & Soraya: Assalamualaikum Pak Amran \\
\hline & $\mathrm{L} 12$ & Pak Amran: Waalaikumsalam, Soraya \\
\hline & L13 & Soraya: A kilo of beef \\
\hline & L14 & Pak Amran: Usually, your Mum buys one and a half kilos. \\
\hline & L15 & Soraya: oh, really? Sure \\
\hline & L16 & Pak Amran: Here, have the tenderloin. Cooks tenderly quickly. \\
\hline & L17 & Soraya: Sure \\
\hline & L18 & Soraya: Lemon grass, pepper, turmeric slices \\
\hline & L19 & $\begin{array}{l}\text { Soraya: Hi Aunty Jayanthi, can I have a kilo of coconut milk } \\
\text { please? }\end{array}$ \\
\hline & $\mathrm{L} 20$ & Auntie Jayanthi: Hey, Soraya. It's been awhile. \\
\hline & $\mathrm{L} 21$ & Soraya: I've been busy in studies \\
\hline & $\mathrm{L} 22$ & Soraya: Eh Kumar, you're on holiday too? \\
\hline & L23 & $\begin{array}{l}\text { Auntie Jayanthi: Is one kilo enough? Your Mum always buys two } \\
\text { kilos. }\end{array}$ \\
\hline & $\mathrm{L} 24$ & Soraya: Oh really? In that case l'll have two kilos. \\
\hline & $\mathrm{L} 25$ & $\begin{array}{l}\text { Kumar: Today you buy kerisik. Who knows tomorrow, I might } \\
\text { merisik? }\end{array}$ \\
\hline & $\mathrm{L} 26$ & Soraya: I've got to go \\
\hline & $\mathrm{L} 27$ & Soraya: Uncle Chong \\
\hline & $\mathrm{L} 28$ & Uncle Chong: Hey Su \\
\hline & $\mathrm{L} 29$ & Soraya: Do you have Asam keeping? \\
\hline & L30 & $\begin{array}{l}\text { Uncle Chong: Of course I do? Your Mum loves this, it's } \\
\text { homemade. }\end{array}$ \\
\hline & $\mathrm{L} 31$ & Uncle Chong: Anything else? \\
\hline & L32 & Soraya: Nothing else, I think... \\
\hline & L33 & Soraya: Eh, Gula Melaka \\
\hline & L34 & Uncle Chong: It's okay, I give you free. \\
\hline & $\mathrm{L} 35$ & Soraya: Thank You uncle Chong, Bye \\
\hline
\end{tabular}




\begin{tabular}{|c|c|c|}
\hline & L36 & $\begin{array}{l}\text { Mother: Remember, slice the meat against the grain, so it won't } \\
\text { be chewy. Stir it well. }\end{array}$ \\
\hline & L37 & Mother: Thought you wanted to be a chef? \\
\hline & L38 & $\begin{array}{l}\text { Mother: Don't forget my secret ingredient. Who else is going to } \\
\text { remember it when I'm gone? }\end{array}$ \\
\hline & L39 & $\begin{array}{l}\text { Mother: If your rendang doesn't work, no one's going to marry } \\
\text { you. }\end{array}$ \\
\hline & $\mathrm{L} 40$ & $\begin{array}{l}\text { Soraya: Father, before going to the mosque, have something to } \\
\text { eat. }\end{array}$ \\
\hline & L41 & $\begin{array}{l}\text { Father: Bismillarhirahmanirahim. Your rendang is so delicious, } \\
\text { Ros. What I mean, the rendang you've cooked Soraya, tastes } \\
\text { just like your late Mother's. }\end{array}$ \\
\hline \multirow{11}{*}{$\begin{array}{c}\text { A2 } \\
\text { Maxis }\end{array}$} & L1 & Father: My son Faiz, is just like any other kid \\
\hline & $\mathrm{L} 2$ & Even when he fasts, his curiosity gets the best of him...and me. \\
\hline & L3 & Solat or Khutbah? Yes, he gets restless too. \\
\hline & L4 & Once in a while, he loses track of time. \\
\hline & L5 & Faiz, my son. I love him just the same. \\
\hline & L6 & No matter how different he experiences the world. \\
\hline & L7 & He can't hear the beautiful sound of Takbir. \\
\hline & L8 & $\begin{array}{l}\text { Still, he never fails to follow me to the mosque every Raya } \\
\text { morning. }\end{array}$ \\
\hline & L9 & But this year, Raya is going to be special for him. \\
\hline & L10 & $\begin{array}{l}\text { This year he will get to feel the Takbir and join others } \\
\text { celebrating for the first time in his life. }\end{array}$ \\
\hline & L11 & In visual copy: Experiences are more meaningful when shared. \\
\hline \multirow{6}{*}{$\begin{array}{c}\text { A3 } \\
100 \text { Plus }\end{array}$} & L1 & Kid: Thank You Kakak \\
\hline & $\mathrm{L} 2$ & Kakak: It is our duty and responsibility \\
\hline & L3 & Man: Thank you for your care and assistance \\
\hline & L4 & Member of the public are the heroes of society and the nation \\
\hline & $\mathrm{L} 5$ & Thank you, sincerely from the heart. \\
\hline & L6 & Narrator: Selamat Hari Raya Aidil Firtri \\
\hline \multirow{5}{*}{$\begin{array}{l}\text { A4 } \\
\text { Hong Leong } \\
\text { Bank }\end{array}$} & L1 & I have 4 sisters \\
\hline & $\mathrm{L} 2$ & My eldest sister, her name is Sara. She wants to be a Doctor \\
\hline & L3 & $\begin{array}{l}\text { My second sister's her name is Aliya. She's likes to cook. She } \\
\text { wants to be a chef }\end{array}$ \\
\hline & L4 & My twin sisters want to be famous. \\
\hline & L5 & But we have never met \\
\hline \multirow{4}{*}{$\begin{array}{c}\text { A5 } \\
\text { Tesco }\end{array}$} & L1 & I often ask a lot \\
\hline & $\mathrm{L} 2$ & What is it that I need to do \\
\hline & L3 & To make Raya more meaningful \\
\hline & L4 & $\begin{array}{l}\text { Does it start from the heart that is sincere giving, without } \\
\text { expecting a return? }\end{array}$ \\
\hline
\end{tabular}




\begin{tabular}{|c|c|c|}
\hline & L5 & Or sharing our blessing in this holy month with those who need? \\
\hline & L6 & No matter where we are \\
\hline & $\mathrm{L} 7$ & Because I realise every good deed that I do \\
\hline & L8 & No matter how big or small \\
\hline & L9 & Gives inspiration to others \\
\hline & L10 & May this Hari Raya mean more with goodness shared together \\
\hline \multirow{6}{*}{$\begin{array}{c}\text { A6 } \\
\text { Ministry of } \\
\text { Economic } \\
\text { Affairs }\end{array}$} & L1 & Pak Ali: Haa everyone's coming home? \\
\hline & $\mathrm{L} 2$ & Friend 1: How many grand children does Pak Ali have? \\
\hline & L3 & Pak Ali: 31 \\
\hline & L4 & Friend: 31 , wahh it will be hard to give Raya money \\
\hline & $\mathrm{L} 5$ & Women neighbour: What are you cooking Pak Ali? \\
\hline & L6 & $\begin{array}{l}\text { Pak Ali: Am cooking dodol. Can have it for breaking fast. Do you } \\
\text { want? }\end{array}$ \\
\hline \multirow{17}{*}{$\begin{array}{l}\text { A7 } \\
\text { TNB }\end{array}$} & L1 & $\begin{array}{l}\text { Girl: Yay Konvoi. This year, we are visiting all of Grandfather's } \\
\text { siblings. It's really a lot. }\end{array}$ \\
\hline & $\mathrm{L} 2$ & Kid: Sister, I want Raya money? \\
\hline & L3 & Girl: There are Aunties that are younger \\
\hline & L4 & Niece's that are older \\
\hline & $\mathrm{L} 5$ & Old lady: Who's child is this? \\
\hline & L6 & Girl: Eh I don't know this great grandma \\
\hline & L7 & $\begin{array}{l}\text { Grandfather: Let's go everyone! There's a lot more house we } \\
\text { need to visit }\end{array}$ \\
\hline & L8 & Girl: Yes grandfather \\
\hline & L9 & Girl: Grandfather.. where are we going? \\
\hline & L10 & Girl: Yay we're at our 8 th, $9^{\text {th }}$ and $10^{\text {th }}$ house \\
\hline & L11 & Girl: Mission accomplished! \\
\hline & $\mathrm{L} 12$ & Girl: Ha? \\
\hline & L13 & Everyone: We're here to Raya! \\
\hline & L14 & Girl: Meeting again? \\
\hline & L15 & $\begin{array}{l}\text { Father: Even though we went to their house, it is their turn to } \\
\text { come to our house }\end{array}$ \\
\hline & L16 & Girl: It's right what Abah said, when we seldom meet. \\
\hline & L17 & Every time we meet, brings a lot of meaning \\
\hline \multirow{9}{*}{$\begin{array}{l}\text { A8 } \\
\text { Astro }\end{array}$} & L1 & Every family must have different kind of attitudes, right? \\
\hline & $\mathrm{L} 2$ & There's a lot taller \\
\hline & L3 & There's the one who shines bright \\
\hline & L4 & Then there's one who likes to makes things \\
\hline & $\mathrm{L} 5$ & There's one that likes to be stylish \\
\hline & L6 & Then there's those who change cars because they are successful \\
\hline & $\mathrm{L} 7$ & And then there's the normal one's \\
\hline & L8 & $6^{\text {th }}$ sibling: Where's Kak Su? \\
\hline & L9 & $\begin{array}{l}\text { Mother: Kak Su went missing and you guys didn't even realise? } \\
\text { Find her now! }\end{array}$ \\
\hline
\end{tabular}




\begin{tabular}{|c|c|c|}
\hline & L10 & All siblings: Kak Su!! \\
\hline & L11 & Then there's the shy one \\
\hline & $\mathrm{L} 12$ & Actually, it doesn't matter if we are more or less \\
\hline & L13 & But when we are together, our Raya is perfect \\
\hline \multirow{37}{*}{$\begin{array}{c}\text { A9 } \\
\text { Media Prima }\end{array}$} & $\mathrm{L} 1$ & Grandpa: Amir, hurry up. The bus us here. \\
\hline & $\mathrm{L} 2$ & Amir: My name is Amir \\
\hline & L3 & $\begin{array}{l}\text { What is my grandpa. He takes care of me while my parents work } \\
\text { in the city }\end{array}$ \\
\hline & L4 & Goodbye, Tok \\
\hline & L5 & Tok always say that after I have gone to school, \\
\hline & L6 & He then gets to do what he loves doing \\
\hline & $\mathrm{L} 7$ & But I actually never know what it is that Tok loves doing. \\
\hline & L8 & Streetside boy: Thank you Pak Din \\
\hline & L9 & Grandpa: No worries, it is nothing... \\
\hline & $\mathrm{L} 10$ & Grandpa, Assalamualaikum. \\
\hline & L11 & Maznah: Waalaikumsalam. \\
\hline & L12 & Grandpa: You ordered a lot of drinks, Maznah \\
\hline & L13 & Maznah: Yes, Pak Din \\
\hline & L14 & $\begin{array}{l}\text { Grandpa: To stay hydrated and active when breaking fast during } \\
\text { Ramadan later, yes? }\end{array}$ \\
\hline & L15 & Maznah: Thank you so much. I have troubled you, Pak Din \\
\hline & L16 & Grandpa: No worries, it is nothing... \\
\hline & L17 & Granpa: Let me carry it. \\
\hline & L18 & Maznah: No need. No Need. Let me carry it. \\
\hline & $\mathrm{L} 19$ & Haqiem: Yes Kak, just the four items, yes? \\
\hline & $\mathrm{L} 20$ & Haqiem: Okay. I will send them in a while \\
\hline & $\mathrm{L} 21$ & Amir: This is Haqiem. He helps Tok to look after the shop. \\
\hline & $\mathrm{L} 22$ & When it comes to mobile phones or gadgets, he is the best \\
\hline & $\mathrm{L} 23$ & The entire village flocks to him. \\
\hline & $\mathrm{L} 24$ & Haqiem: No worries, it's nothing... \\
\hline & $\mathrm{L} 25$ & I am leaving, Pak Din. \\
\hline & $\mathrm{L} 26$ & Grandpa: All right, See you, Haqiem \\
\hline & $\mathrm{L} 27$ & Goodbye. Be careful \\
\hline & $\mathrm{L} 28$ & Amir: Tok, we are back \\
\hline & $\mathrm{L} 29$ & And this is Ah Keong. He is my best friend. \\
\hline & L30 & $\begin{array}{l}\text { He is always here while waiting for his parents to pick him up } \\
\text { after work. }\end{array}$ \\
\hline & L31 & I am happy that we get to play together. \\
\hline & L32 & Goodbye \\
\hline & L33 & Ah Keong: Good Bye \\
\hline & L34 & Grandpa: Okay enough, Let's close for the day. \\
\hline & L35 & $\begin{array}{l}\text { Amir: Tok, if you have supernatural powers, what powers do you } \\
\text { want? }\end{array}$ \\
\hline & L36 & Do you want to be able to fly? \\
\hline & L37 & Or do you want the power to shoot fire? \\
\hline
\end{tabular}




\begin{tabular}{|c|c|c|}
\hline & L38 & Granpa: Why would I want such powers, Amir? \\
\hline & L38 & Amir: You can save the world, Tok. \\
\hline & $\mathrm{L} 40$ & Grandpa: Do you want to be Ejen Ali, Amir? \\
\hline & $\mathrm{L} 41$ & Amir: Of course, I do! \\
\hline & $\mathrm{L} 42$ & Every night, after closing for the day, \\
\hline & $\mathrm{L} 43$ & Tok then has time to spend with me. \\
\hline & L44 & This is our life everyday. \\
\hline & $\mathrm{L} 45$ & But today is unlike the usual. \\
\hline & L46 & Suddenly, something unexpected happened. \\
\hline & $\mathrm{L} 47$ & There is a leak... \\
\hline & L48 & Look at that! \\
\hline & L49 & Help Help! \\
\hline & $\mathrm{L} 50$ & Ah Keong! \\
\hline & $\mathrm{L} 51$ & Oh Dear... \\
\hline & $\mathrm{L} 52$ & Haqiem: Amire. Ah Keong. Come here, come here. \\
\hline & $\mathrm{L} 53$ & Ah Keong \& Amir: Haqiem! \\
\hline & $\mathrm{L} 54$ & Haqiem: Don't you worry,I will get help, okay? \\
\hline & $\mathrm{L} 55$ & Amir: Tok, Tok. You should have seen what happened. \\
\hline & L56 & Haqiem and the others were like heroes, you know? \\
\hline & $\mathrm{L} 57$ & They all helped us. \\
\hline & L58 & In no time, the roof was fixed. \\
\hline & $\mathrm{L} 59$ & Tok. Look, Tok. All these were heroes earlier, Tok. \\
\hline & L60 & Haqiem: Sheesh, Amir. The hero is not us. \\
\hline & L61 & The hero is he who shows concern for others. \\
\hline & L62 & Lady: The hero is someone strong. \\
\hline & L63 & Maznah: Yes. Even my plants are always fresh. \\
\hline & L64 & Ah Keong Mother: The hero has enough love for everyone. \\
\hline & L65 & $\begin{array}{l}\text { Streetside boy: and he helps everyone, regardless of who they } \\
\text { are. }\end{array}$ \\
\hline & L66 & Grandpa: This...I want to say Thank You. \\
\hline & L67 & All of you have helped me. I have troubled all of you. \\
\hline & L68 & Everyone: No worries, Pak Din. It is nothing. \\
\hline & L69 & $\begin{array}{l}\text { Amir: Now I understand what it is that Tok loves doing when I } \\
\text { have gone to school }\end{array}$ \\
\hline & L70 & $\begin{array}{l}\text { To the villagers, he is their hero. But to me, Tok's supernatural } \\
\text { power lies in his advice. }\end{array}$ \\
\hline & L71 & $\begin{array}{l}\text { He always says Be Sincere to others, and they will be sincere to } \\
\text { us too. }\end{array}$ \\
\hline & $\mathrm{L} 72$ & Selamat Hari Raya Aidilfitri! \\
\hline \multirow{6}{*}{$\begin{array}{l}\text { A10 } \\
\text { Unifi }\end{array}$} & L1 & I'm LEMAN. \\
\hline & $\mathrm{L} 2$ & Everyone calls me Leman LEBIH (MORE). \\
\hline & L3 & My principle in life is...everything has to be MORE! \\
\hline & L4 & Well, when there's more, there's no need to fight. \\
\hline & L5 & Sister: I wanna watch my Korean drama! \\
\hline & L6 & Littler brother: I wanna watch! \\
\hline
\end{tabular}




\begin{tabular}{|c|c|l|}
\hline L7 & Leman: Hey, hey, hey! \\
\cline { 2 - 3 } & L8 & You guys are fighting over Korean dramas? \\
\hline L9 & Leman is here lah! \\
\hline L10 & Leman can give you more. \\
\hline L11 & Where there's Leman, there's a way. \\
\hline L12 & Whenever people have problem, they all come to me. \\
\hline L13 & Sister: I can't open the photo you sent me, Leman. \\
\hline L14 & Leman: No wonder sis, you've run out of data. \\
\hline L15 & Be like me - get lots MORE data! \\
\hline L16 & To me, Raya is a time for MORE! \\
\hline L17 & It has to be MORE...so if I... \\
\hline L18 & Sister: It's always MORE with you lah, Leman! \\
\hline L19 & Leman: But all this wanting MORE is not just for me alone. \\
\hline L20 & The More we give, the MORE we get! \\
\hline
\end{tabular}

\begin{tabular}{|c|c|c|}
\hline \multicolumn{3}{|l|}{ CNY } \\
\hline \multirow{11}{*}{$\begin{array}{l}\text { A11 } \\
100 \text { PLUS }\end{array}$} & L1 & Mum: Your result is good enough \\
\hline & $\mathrm{L} 2$ & Mum: Why do you cry? \\
\hline & L3 & Girl: I want to score 100 \\
\hline & L4 & Mum: She reminds me \\
\hline & L5 & We look the same \\
\hline & L6 & I want to score 100 \\
\hline & $\mathrm{L} 7$ & Grandfather: For me, you've already scored more than 100 \\
\hline & L8 & Mum: For me, you've already scored more than 100 \\
\hline & L9 & Let's go back and visit your grandparents \\
\hline & L10 & Girl: Sure \\
\hline & L11 & $\begin{array}{l}\text { All: There's nothing more important than a family reunion } \\
\text { Celebrate a Golden Chinese New Year with 100PLUS }\end{array}$ \\
\hline \multirow{11}{*}{$\begin{array}{l}\text { A12 } \\
\text { Palm Oil }\end{array}$} & L1 & On our way to our new dream \\
\hline & $\mathrm{L} 2$ & Our new home \\
\hline & L3 & Our strides may differ \\
\hline & L4 & Our pace uneven \\
\hline & $\mathrm{L} 5$ & But every stop, every footfall, \\
\hline & L6 & Is taken with purpose \\
\hline & $\mathrm{L} 7$ & We build on each other's strengths \\
\hline & L8 & And learn from each others shortcomings. \\
\hline & L9 & These are the seeds we've sown. \\
\hline & L10 & The future we will reap. \\
\hline & L11 & On this journey, together. \\
\hline \multirow[t]{2}{*}{$\begin{array}{l}\text { A13 } \\
\text { SP Setia }\end{array}$} & L1 & $\begin{array}{l}\text { Grandfather: He lan Shui, the thing we most looked forward to } \\
\text { every Chinese New Year }\end{array}$ \\
\hline & $\mathrm{L} 2$ & It was the only time we got to have it \\
\hline
\end{tabular}




\begin{tabular}{|c|c|c|}
\hline & L3 & He Lan Shui. It would bring great happiness in me. \\
\hline & $\mathrm{L} 4$ & Grandson: Yeh Yeh, would you like some Soda? \\
\hline & L5 & Grandfather: No thank you. I won't have soda but I'll have tea. \\
\hline & L6 & But now, it is tea that brings me great happiness. \\
\hline & $\mathrm{L} 7$ & For just a pot of hot tea can bring a whole family together. \\
\hline & L8 & $\begin{array}{l}\text { Even the distance between the cups is closer than the distance } \\
\text { between the people }\end{array}$ \\
\hline & L9 & $\begin{array}{l}\text { They may be served in small cups, but is so we have more } \\
\text { opportunities to give and receive. }\end{array}$ \\
\hline & L10 & Grandson: Yeh Yeh, I want a cup too! \\
\hline & L11 & Grandfather: Sure, my dear! \\
\hline & $\mathrm{L} 12$ & Let's share a cup of tea together. \\
\hline & L13 & One pot to warm the entire family. \\
\hline & $\mathrm{L} 14$ & Setia wishes you a Happy Chinese New Year. Stay Close. \\
\hline \multirow{12}{*}{$\begin{array}{l}\text { A14 } \\
\text { KFC }\end{array}$} & $\mathrm{L} 1$ & Man: Too red? \\
\hline & $\mathrm{L} 2$ & Narrator: Go redder \\
\hline & L3 & Lady: Too big? \\
\hline & $\mathrm{L} 4$ & Narrator: Nahh, Go bigger. Woahhhh, oops \\
\hline & L5 & Grandfather: Hey only you? \\
\hline & L6 & Narrator: No uncle, more grandchildren! \\
\hline & $\mathrm{L} 7$ & Narrator: Yeah, now let's fiest! \\
\hline & L8 & Kid: KFC! \\
\hline & L9 & Narrator : Wait kid, there's more! \\
\hline & L10 & Kid: More? \\
\hline & $\mathrm{L} 11$ & Narrator: Yes, more! \\
\hline & L12 & $\begin{array}{l}\text { Fried mashed potato fingers! Go big with KFC celebration bucket. } \\
\text { Bring more to the table. }\end{array}$ \\
\hline \multirow{8}{*}{$\begin{array}{l}\text { A15 } \\
\text { McDonald }\end{array}$} & $\mathrm{L} 1$ & Man: I don't need a lot, \\
\hline & $\mathrm{L} 2$ & Or anything new. \\
\hline & $\mathrm{L} 3$ & Woman: I know the journey might not be smooth. \\
\hline & $\mathrm{L} 4$ & Man: and the weather...might not be good. \\
\hline & L5 & I don't need a big crowd... \\
\hline & L6 & Woman: I don't need a grand meal. \\
\hline & $\mathrm{L} 7$ & I don't need spectacular fireworks... \\
\hline & L8 & Man: Because for me...You are my prosperity. \\
\hline \multirow[t]{4}{*}{$\begin{array}{l}\text { A16 } \\
\text { TNB }\end{array}$} & L1 & $\begin{array}{l}\text { In-video copy (Supers): } \\
\text { Locked Lah }\end{array}$ \\
\hline & $\mathrm{L} 2$ & Can fit meh? \\
\hline & $\mathrm{L} 3$ & Yaass \\
\hline & $\mathrm{L} 4$ & Will they escape? \\
\hline $\begin{array}{l}\text { A17 } \\
\text { IJM Land }\end{array}$ & $\mathrm{L} 1$ & $\begin{array}{l}\text { Boy: When I was young, I secretly take Two Mandarin oranges for } \\
\text { Ali and Muthu }\end{array}$ \\
\hline
\end{tabular}




\begin{tabular}{|c|c|c|}
\hline & $\mathrm{L} 2$ & While my mother was preparing the reunion dinner \\
\hline & $\mathrm{L} 3$ & When we grow older, we are still neighbours \\
\hline & $\mathrm{L} 4$ & Living in a serene and peaceful environment \\
\hline & $\mathrm{L} 5$ & Our relationships remain the same \\
\hline & L6 & We celebrate every festive season together \\
\hline & $\mathrm{L} 7$ & IJM land wishes everyone peace and harmony abundance of joy \\
\hline & L8 & All the best \\
\hline \multirow{6}{*}{$\begin{array}{l}\text { A18 } \\
\text { McDonald } \\
\text { Tactical }\end{array}$} & $\mathrm{L} 1$ & Especially for you this Chinese New Year \\
\hline & $\mathrm{L} 2$ & Fresh Fish Fillet \\
\hline & L3 & Battered and fried to golden perfection \\
\hline & $\mathrm{L} 4$ & Dipped in our signature black pepper sauce \\
\hline & $\mathrm{L} 5$ & Enjoy more abundance with the new fish prosperity burger \\
\hline & L6 & Only at McDonalds \\
\hline \multirow{9}{*}{$\begin{array}{l}\text { A19 } \\
\text { Hurix }\end{array}$} & $\mathrm{L} 1$ & Chinese New Year is Here! \\
\hline & $\mathrm{L} 2$ & Chinese New Year is Here! \\
\hline & L3 & Mmm... The money rolls in. \\
\hline & L4 & Great Fortunes, I'm back! \\
\hline & $\mathrm{L} 5$ & Success in career \\
\hline & L6 & Bring in wealth and treasure \\
\hline & $\mathrm{L} 7$ & Waaa, This must be Surplus year after year \\
\hline & L8 & Grandma, all the Chinese New Year Wishes are all written down! \\
\hline & L9 & $\begin{array}{l}\text { Grandma wishing everyone Happy Chinese New Year and Pink in } \\
\text { health. }\end{array}$ \\
\hline \multirow{8}{*}{$\begin{array}{l}\text { A20 } \\
\text { Vitagen }\end{array}$} & L1 & Make sure you guys address all the elders ah! \\
\hline & $\mathrm{L} 2$ & Hi, Happy Chinese New Year! \\
\hline & L3 & $\begin{array}{l}\text { Aunty (Father's elder Brother's Wife), Cousin (Abang), Uncle } \\
\text { (Father's 7th Uncle), Cousin (Sister), Aunty (Father's younger } \\
\text { brother's wife) \& Uncle (Father's younger brother), Aunty } \\
\text { (Father's elder sister), Uncle (Father's elder brother), GongGong } \\
\text { (Grandfather) Popo (Grandmother) }\end{array}$ \\
\hline & L4 & Gong Xi Fa Chai \\
\hline & $\mathrm{L} 5$ & Wa, all your children are so smart! \\
\hline & L6 & $\begin{array}{l}\text { Because they drink Vitagen that consists of probiotics, hence they } \\
\text { have a very good gut health, crystal clear in mind. }\end{array}$ \\
\hline & $\mathrm{L} 7$ & Vitagen adhere to wish everyone Happy Chinese New Year! \\
\hline & L8 & GONG XI FA CHAI \\
\hline
\end{tabular}

\section{OTHERS}

Deepavali

A21

Petronas

L1 Grandmother: My grandson, even though your near to the eyes, but far from the heart. 


\begin{tabular}{|c|c|c|}
\hline & & Kumar, open the door. \\
\hline & $\mathrm{L} 2$ & Open the door. \\
\hline & L3 & My own grandson doesn't know Tamil. \\
\hline & $\mathrm{L} 4$ & But through is willingness, he opened his heart to me. \\
\hline & $\mathrm{L} 5$ & Grandson: Nenek. You talk, I listen. Can? \\
\hline & L6 & Grandmother: My heart. \\
\hline & $\mathrm{L} 7$ & Grandson: Grandmother. \\
\hline & L8 & $\begin{array}{l}\text { In-visual copy: An open heart, welcomes the most precious } \\
\text { blessings. }\end{array}$ \\
\hline \multirow{14}{*}{$\begin{array}{l}\text { A22 } \\
\text { TNB }\end{array}$} & $\mathrm{L} 1$ & Boy: Mummm!!! \\
\hline & $\mathrm{L} 2$ & Why are you doing this to me? \\
\hline & L3 & This is my Mother, she really likes watching old films. \\
\hline & $\mathrm{L} 4$ & But every time it's Deepavali, I am her victim. \\
\hline & L5 & $\begin{array}{l}\text { I want to be stylish like the heroes of today, not like old trends } \\
\text { Mum! }\end{array}$ \\
\hline & L6 & Mother: Why son? Is it not pretty? \\
\hline & $\mathrm{L} 7$ & MGR darling, let's go to the temple \\
\hline & L8 & Boy: What? Temple? \\
\hline & L9 & Mother: MGR! Shine like a diamond! \\
\hline & L10 & Boy: Keerthi must also be at the temple later too \\
\hline & L11 & Wah! Look at that, like the heroin in the old films \\
\hline & L12 & Keerthi: Looks like the same story happened in both our houses \\
\hline & L13 & Mother: MGR \\
\hline & L14 & $\begin{array}{l}\text { Boy: Eventhough time has changed and we have grown, our } \\
\text { parents always make sure that we shine bright. }\end{array}$ \\
\hline \multirow{6}{*}{$\begin{array}{l}\text { A23 } \\
\text { Astro }\end{array}$} & $\mathrm{L} 1$ & Emcee: and now, please welcome our next contestant \\
\hline & $\mathrm{L} 2$ & And 3, 21 music \\
\hline & L3 & Cut \\
\hline & $\mathrm{L} 4$ & SFX *Heart thumping fast \\
\hline & $\mathrm{L} 5$ & Narrator: May love light your way. \\
\hline & L6 & We wish you a very happy Deepavali \\
\hline \multirow{8}{*}{$\begin{array}{l}\text { A24 } \\
\text { Astro } \\
\text { Ulagam }\end{array}$} & $\mathrm{L} 1$ & Malay Boy: Hey Bro, what do you guys do for deepavali? \\
\hline & $\mathrm{L} 2$ & Indian Boy: Deepavali? \\
\hline & L3 & Come let me show you. Amma! \\
\hline & $\mathrm{L} 4$ & All 3: Deepavali Ayy Ayy! Deepavali Ayy Ayy! \\
\hline & L5 & Indian: Welcome \\
\hline & L6 & Indian: If I've told you once,I've told you a hundred times. \\
\hline & $\mathrm{L} 7$ & Indian Mother: It's okay. Auntie will do it. \\
\hline & L8 & All three: Deepavali hey hey! \\
\hline \multicolumn{3}{|l|}{ Gawai } \\
\hline A25 & $\mathrm{L} 1$ & I am 33 years old \\
\hline
\end{tabular}




\begin{tabular}{|c|c|c|}
\hline \multirow[t]{13}{*}{ Finas } & & \\
\hline & L2 & My body feels so tired today \\
\hline & L3 & $\begin{array}{l}\text { This is my mother. Every time it's Gawai, she's busy cooking } \\
\text { glutinous rice }\end{array}$ \\
\hline & L4 & Oh no, \\
\hline & L5 & Auntie: Gawai this year, did you bring a wife? \\
\hline & L6 & Why are you not married yet? \\
\hline & L7 & Man: I already predicted every year the same question \\
\hline & L8 & Every year, they are all busy with Gawai preparation \\
\hline & L9 & Who's that? \\
\hline & L10 & Woman: I just arrived Mum, Yes okay Mum. \\
\hline & L11 & Uncle: How are you Gudum? \\
\hline & L12 & This is my wife Velvet, from Sabah \\
\hline & L13 & Gudum: Aduh! Looks like l'Il be single this year again. \\
\hline \multicolumn{3}{|l|}{ Kaamatan } \\
\hline \multirow{6}{*}{$\begin{array}{l}\text { A26 } \\
\text { Petronas }\end{array}$} & L1 & Even though Daddy is no longer with us, but every Kaamatan \\
\hline & $\mathrm{L} 2$ & I always remember what he said \\
\hline & L3 & the most important gift is family and tradition \\
\hline & L4 & This gift is what has shaped who Daddy is and my heart and soul \\
\hline & L5 & $\begin{array}{l}\text { In-visual copy: Family and tradition. A gift that actually resembles } \\
\text { us. }\end{array}$ \\
\hline & L6 & Kotobian Tadau Tagazo Do Kaamatan \\
\hline \multicolumn{3}{|l|}{ Christmas } \\
\hline \multirow{3}{*}{$\begin{array}{l}\text { A27 } \\
\text { Ferrero } \\
\text { Rocher }\end{array}$} & L1 & Christmas is the golden time \\
\hline & L2 & So enjoy the taste and festivities together with Ferero Rocher \\
\hline & L3 & As precious as our loved one \\
\hline \multirow[t]{3}{*}{$\begin{array}{l}\text { A28 } \\
\text { Kinder Joy }\end{array}$} & L1 & $\begin{array}{l}\text { Choose kinder joy, because of the delicious coco and milky cream } \\
\text { with chrispy wafer balls }\end{array}$ \\
\hline & L2 & Toys that stimulate imagination and a moment of family joy \\
\hline & L3 & Merry Christmas with Kinder Joy \\
\hline
\end{tabular}

